Lopes-Martínez, I., Paradela-Fournier, L., Rodríguez-Acosta, J., Castillo-Feu, J., Gómez-Acosta, M., \& Cruz-Ruiz, A. (2018). Using AUTO-ID technologies in the Cuban drug logistics system to increase its safety and efficiency. Sistemas \& Telemática, 16(44), 35-48.

Discussion paper / Artículo de reflexión / Documento de discussão - Tipo 2

\title{
Using AUTO-ID Technologies in the Cuban Drug Logistics System to Increase its Safety and Efficiency
}

Igor Lopes Martínez / ilopes@ind.cujae.edu.cu

Lianet Paradela Fournier / Iparadelaf@ind.cujae.edu.cu

Janett Rodríguez Acosta / jracosta@tesla.cujae.edu.cu

Jenny Laura Castillo Feu / jennylaura.castillo@nauta.cu

Martha I. Gómez Acosta / marthagom@tesla.cujae.edu.cu

Departamento de Ingeniería Industrial, Universidad Tecnológica de La Habana José Antonio Echeverría, Cuba

Alegna Cruz Ruiz / alegna@psico.uh.cu

Facultad de Psicología, Universidad de La Habana, Cuba

ABSTRACT This research was conducted involving five of the main supply chain of medicines in Cuba actors, including, since suppliers of medicines and the 3PL logistics operator, to healthcare centers and pharmacies. A diagnosis of the current state of the system of coding and classification of products was made. This activity showed, as main deficiencies, ineffectiveness on the products identification, since there are problems with codes, descriptions and units of measurements. A procedure to implement the AUTO-ID and EDI technologies proposed by GS1, was also designed, based on evaluating the effectiveness of these technologies in global logistics.

KEYWORDS AUTO-ID; EDI; GS1 international standards; coding; classifier; traceability; supply chain.

Uso de las tecnologías de AUTO-ID en el sistema logístico de medicamentos en Cuba para incrementar su seguridad y eficiencia

RESUMEN La investigación que se reporta fue desarrollada involucrando cinco actores de la cadena de suministro de medicamentos en Cuba, que abarcan desde los proveedores de medicamentos y el operador logístico 3PL, hasta los centros asistenciales y las farmacias. Se realizó un diagnóstico del estado actual del sistema de codificación y clasificación de productos, lo que arrojó, como principales deficiencias, la inefectividad en la identificación de los productos, ya que existen problemas con los códigos, las descripciones y las unidades de medidas. Se diseñó además un procedimiento para implementar las tecnologías de AUTO-ID y EDI que propone GS1, a partir de evaluar la efectividad de estas tecnologías en la logística global.

PALABRAS CLAVE AUTO-ID; EDI; estándares internacionales GS1; codificación; clasificador; trazabilidad; cadena de suministro.
Uso de tecnologias AUTO-ID no sistema logístico de medicamentos em Cuba para aumentar sua segurança e eficiência

RESUMO A pesquisa relatada foi desenvolvida envolvendo cinco atores na cadeia de abastecimento de medicamentos em Cuba, que vão desde os fornecedores de medicamentos e o operador logístico 3PL, até os centros de saúde e farmácias. Foi elaborado um diagnóstico do estado atual do sistema de codificação e classificação dos produtos, o que mostrou, como principais deficiências, a ineficácia na identificação dos produtos, uma vez que existem problemas com os códigos, as descrições e as unidades de medidas. Foi desenhado um procedimento para implementar as tecnologias AUTO-ID e EDI propostas pela GS1, com base na avaliação da eficácia dessas tecnologias na logística global.

PALAVRAS-CHAVE AUTO-ID; EDI; padrões internacionais GS1; codificação; classificador; rastreabilidade; cadeia de abastecimento. 


\section{Introduction}

Supply chains, in general, are vulnerable to risks, especially regarding to traceability. In the pharmaceutical industry, it has generated facts all over the world that show the circulation of illicit medicines (WHO, 2017). Sub-Saharan Africa, India, Central, and South Ameri$\mathrm{ca}$, are the regions where a higher incidence is reported, it is stated that between $20 \%$ and $50 \%$ of medicines are illegal ("Comercio ilegal...", 2010).

In Cuba, according to information from the regulatory agency of the sector, the Center for the State Control of Medicines, Equipment and Medical Devices [CEGMED, Centro para el Control Estatal de Medicamentos, Equipos y Dispositivos Médicos], until 2016, has made several withdrawals from the market and communications of risks, due to quality problems in the medications (CECMED, 2017).

The traceability throughout the logistics system is a requirement in the drugs supply chains, then, it is necessary that products are correctly identified, which means that they can be identified in an unique way in each control point (ISO/IEC FDIS 15459-4:2014; NC-ISO 22005:2008; Krähenbühl \& Haynes, 2012).

The unique identification is supported by the ISO/IEC FDIS 15459-4:2014 standard (Park, Zo, Ciganek, \& Lim, 2011), which in session 4 standardizes the form of identification to all packaging levels and the relationship between the codes of each level. Its proposal focuses on all the actors in the chain using the standard to communicate and guarantee interoperability between information systems.

In the health field, Automatic Identification and Data Capture [AIDC] has been considered by the regulatory agencies as crucial in patient safety and in the accuracy and reliability of logistics. Since 1984, the Healthcare Industry Bar Code [HIBC] has been used as a way to capture data quickly and safely. Promoted by the International Medical Device Regulators Forum [IMDRF], with members such as the Food and Drug Administration [FDA] of the United States of America, the European Commission, an international project called Unique Device Identification [UDI] is started, which includes the AIDC as a center in the marking of the loads and as a data standard in the interoperable databases. The UDI was imposed as Federal Law in the United States in 2013, as the basis for its generalization from that year.

Information and communication technologies have revolutionized the supply chains, have made them safer

\section{Introducción}

Las cadenas de suministro, en general, son vulnerables a riesgos, especialmente en lo relativo a la trazabilidad. En la industria farmacéutica, con los medicamentos, han ocurrido hechos en todo el mundo que evidencian la circulación de medicamento ilícitos (WHO, 2017). África Subsahariana, la India, Centroamérica y Sudamérica, son las regiones donde se reporta una mayor incidencia, se plantea que entre un 20\% a un $50 \%$ de los medicamentos son ilícitos ("Comercio ilegal..., 2010).

En Cuba, según información de la agencia reguladora del sector, el Centro para el Control Estatal de Medicamentos, Equipos y Dispositivos Médicos [CECMED], hasta el 2016 se han realizado varias retiradas del mercado y comunicaciones de riesgos debido a problemas en la calidad de los medicamentos (CECMED, 2017).

La trazabilidad en todo el sistema logístico es una exigencia en las cadenas de suministros de medicamentos, para ello es necesario que los productos estén correctamente identificados, lo cual significa que en cada punto de control deben poder ser identificados de forma única (ISO/IEC FDIS 15459-4:2014; NC-ISO 22005:2008; Krähenbühl \& Haynes, 2012).

La identificación única está sustentada en la norma ISO/ IEC FDIS 15459-4:2014 (Park, Zo, Ciganek, \& Lim, 2011). Esta, entre otros elementos, en la parte 4 estandariza la forma de identificación a todos los niveles de embalaje y la relación entre los códigos de cada nivel. Su propuesta se centra en que todos los actores de la cadena utilicen el estándar para comunicarse y así garantizar interoperabilidad entre los sistemas de información.

En el área de salud, la identificación automática y captura de datos [AIDC, Automatic Identification and Data Capture] ha sido considerada por las agencias reguladoras como crucial en la seguridad del paciente y en la exactitud y fiabilidad de la logística. Desde 1984 se utiliza el Healthcare Industry Bar Code [HIBC], como una forma de capturar los datos de manera rápida y segura. Promovido por el International Medical Device Regulators Forum [IMDRF], con miembros como la Food and Drug Administration [FDA] de los Estados Unidos de América, la Comisión Europea, se comienza un proyecto internacional llamado Unique Device Identification [UDI, el cual incluye la AIDG como centro en el marcaje de las cargas y como estándar de datos en las bases de datos interoperables. El UDI fue impuesto como Ley Federal en los Estados Unidos en 2013, sirviendo de base para su generalización a partir de ese año.

Las tecnologías de la información y las comunicaciones han revolucionado las cadenas de suministros, las han hecho más seguras y eficientes, es por eso que el presente artículo tiene como objetivo evaluar las condiciones actuales y requerimientos necesarios para la implementación de un procedimiento para la introducción de las tecnologías Auto-ID [Automatic Identification] y EDI [Electronic Data Interchange] en la cadena de suministro de medicamentos en Cuba. La utilización de estas tecnologías está ampliamente abordada en la literatura, pero además, entre otras normativas se han identificado las siguien- 
tes como sustento de la propuesta: la ISO/IEC 15424:2008 (Ferrer-Roca, 2011), la ISO 17367:2013 y la ISO/FDIS 29161:2016, todas sustentando incluso el advenimiento de las tecnologías habilitadoras de la logística 4.0.

\section{Materiales y métodos}

El alcance de la presente investigación abarca a cinco actores de la cadena de suministro: las unidades importadoras, los productores nacionales, el operador logístico 3PL de la cadena y los centros asistenciales y farmacias comunitarias.

Se utiliza, para la evaluación del sistema de codificación, el módulo Sistemas de Codificación y Clasificación de los productos del Modelo de Referencia de los Inventarios, con la aplicación de la herramienta MRInv (Martínez, 2013). Este módulo constituye una lista de chequeo con treinta descriptores cuyo objetivo es evaluar aspectos relacionados con el nivel de estandarización de los sistemas de codificación que deben utilizar las empresas, se orienta la utilización de sistemas de clasificación y codificación regulados en el país y la correcta utilización de las unidades de medida en estos sistemas. Cada descriptor se evalúa en una escala de 0 a 3 puntos de acuerdo con el nivel que tiene en el sistema logístico; se asigna 0 , cuando no existe la práctica descrita; y 3 cuando su aplicación es de un nivel alto. Esta estructura permite determinar los aspectos individuales y los módulos que constituyen debilidades y fortalezas, para luego definir los planes de acción que permitirán el mejoramiento de la gestión de inventario.

Las principales herramientas empleadas durante la investigación fueron: la observación directa, las entrevistas a expertos, el benchmarking, el análisis de bases de datos extraídas de los sistemas de información de las entidades, el uso del MS Excel y MS Visio y el análisis bibliográfico.

\section{Resultados}

El uso de la identificación automática para captar los datos de los productos es una debilidad del sistema logístico de medicamentos en Cuba. La causa fundamental es la débil utilización de los estándares de codificación en los diferentes niveles de empaque (Martínez, 2013).

Para contribuir en la solución de este problema, se propone el uso de al menos dos códigos para cada producto, un código de clasificación y otro de identificación única. En el caso de la clasificación la propuesta se sustenta en la necesidad de organizar los productos de manera que permita gestionar el inventario en grupos que tengan un significado lógico para la cadena de medicamentos, lo cual no se garantiza con la aplicación directa del clasificador nacional propuesto por la Oficina Nacional de Estadística e Información [ONEI]. Para el sistema de codificación se realiza la propuesta sustentada en los estándares GS1 para todos los niveles de empaque.

A. Utilización de las tecnologías Auto-ID y EDI en el sector de la salud En la práctica se evidencia que, mientras no se estandaricen los datos con los que deben trabajar los sistemas informá- and more efficient, that is why this article aims to evaluate the present conditions and the requirements for implementing a procedure to introduce technologies Auto-ID [Automatic Identification] and EDI [Electronic Data Interchange] technologies in the drug supply chain in Cuba.

The use of these technologies is widely addressed in the literature, but also, among other regulations have identified the following as support for the proposal: ISO/ IEC 15424:2008 (Ferrer-Roca, 2011), ISO 17367:2013 and ISO/FDIS 29161:2016, all supporting the advent of enabling technologies for logistics 4.0.

\section{Materials and Methods}

The present research covers five actors in the supply chain: the importing units, the national producers, the 3PL logistics operator of the chain, and the health care centers and community pharmacies.

The Module for Coding and Classification of the products of the Reference Model of the Inventories is used for the appraisal of the codification system, with the application of the MRInv tool (Martínez, 2013). This module constitutes a checklist with thirty descriptors whose objective is to evaluate aspects related to the level of standardization of the coding systems that companies must use. The use of classification and coding systems regulated in the country and the correct use of the units of measurement in these systems is oriented. Each descriptor is evaluated using a 0 to 3 points scale, according to its level in the logistical system. " 0 " is assigned when the described practice is not exist and " 3 " when there is a high level of application. This structure lets determine the individual aspects and the modules constituting weaknesses or strengths, to then define the action plans that will allow the improvement of inventory management.

The main tools used during this research were: direct observation, interviews with experts, benchmarking, analysis of databases extracted from the information systems of the entities, the use of the MS Excel and MS Visio, and the bibliographic analysis.

\section{Results}

The use of automatic identification to obtain the data from products is a weakness of Cuban drugs logistic system. Its main cause is the low level of use of codification standards in the levels of packing (Martínez, 2013). In order to contribute to the solution of that problem, we propose the use of, at least, two codices for each product, 
one for classification, other for unique identification. For classification, the propose is supported in the need to organize the products in a way that allows managing the inventory in groups within a logical meaning for the chain of medicines, which is not guaranteed with the direct application of the national classifier proposed by the National Office of Statistics and Information [ONEI, Organización Nacional de Estadística e Información). For the coding system, the proposal is based on GS1 standards to be carried out for all packaging levels.

\section{A. Use of Auto-ID y EDI Technologies in the Health Sector}

The fact evidences that when there is not a data standardization needed by the computer systems through the whole drugs supply chain, and there isa manual introduction of the product data, these systems won't be efficient. It may be issuing late, unreal, and ambiguous information about the state of the products.

To face this issue, the drug supply chain must adopt a system of coding and classification of its products, supported by an efficient technological infrastructure. There are only 39 agencies which emit Universal Device Identifier[UDI] codes, which can answer this need, including:

- Health Industry Business Communications Council [HIBCG];

- International Council for Commonality in Blood Banking Automation [ICCBBA];

- Eurodata Council [EDG];

- AIM [Association for Automatic Identification and Mobility];

- CEFIC [Chemical Industries Association];

- EDIFICE, for B2B business;

- ODETTE, for automotive industry;

- DIN [Deutshes Institut forCooperation]; and

- GS1.

These companies or groups develop their own identification, classification, and data capture systems; based on standards and the conception that a product or a device is identified in a single way globally. Others use standards that are only functional within the confines of a single industry or a single country. The system of standards proposed by GS1 is one of the most used because it is global, solid, and multisectorial. It is also generated for the user and is scalable (GSI, 2011).

The GS1 standards system is a flexible architecture that ensures maximum efficiency. It is built around and on two ticos en toda la cadena de suministro de medicamentos y continúe la introducción manual de los datos del producto, estos sistemas no serán eficientes, pues podrán estar emitiendo información tardía, irreal y ambigua sobre el estado de los productos.

Para enfrentar este problema la cadena de suministro de medicamentos debe adoptar un sistema de codificación y clasificación estándar de sus productos, soportado en una eficiente infraestructura tecnológica. Existen solo 39 agencias emisoras de códigos de identificación global [UDI, Universal Device Identifier] que pueden responder esta necesidad, entre ellas:

- Health Industry Business Communications Council [HIBCG];

- International Council for Commonality in Blood Banking Automation [ICCBBA];

- Eurodata Council [EDC];

- AIM [Association for Automatic Identification and Mobility];

- CEFIC [Chemical Industries Association];

- EDIFICE, para negocios B2B;

- ODETTE, para la industria automotriz;

- DIN [Deutshes Institut for Cooperation]; y

- GS1.

Estas compañías o grupos desarrollan sus sistemas propietarios de identificación, clasificación y captura de datos, pero todas sustentadas en estándares y en la concepción de que un producto o un dispositivo se identifiquen de una única manera globalmente. Otras utilizan estándares que son únicamente funcionales dentro de los confines de una única industria o un único país. El sistema de estándares propuesto por GS1 es uno de los más utilizados porque es mundial, sólido, multisectorial, es generado para el usuario y escalable (GSI, 2011).

El sistema de estándares GSl es una arquitectura flexible que asegura máxima eficiencia. Se construye alrededor y sobre dos elementos seguros: estándares de identificación automática GS1 y estándares de comunicación. Esta organización tiene representación en 107 organizaciones miembro que atienden 150 países (GSI, 2011). En Cuba su representación se encuentra en la Cámara del Comercio y es nombrada GSl Cuba.

Existen varios sistemas de trazabilidad soportados en los estándares GS1, como el Sistema Nacional de Trazabilidad de Medicamentos en Argentina, el Sistema Nacional de Rastreo y Seguimiento Farmacéutico [ITS] de Turquía, y se están realizando algunas pruebas pilotos soportadas en estos estándares para implementar sistemas nacionales de trazabilidad en Brasil, Colombia y en Egipto (Gonzalez, 2013; Bulaon, 2016; Ünal, 2016; Afify \& Mabrouk, 2014; Derecho \& Sánchez, 2014; Filho, Blanco, \& Ferreira, 2011; GS1, 2013; Brommeyer, 2013).

Las tecnologías que permiten la implementación de estos sistemas basados en los estándares GS1 son la identificación automática de los datos de los productos [Auto-ID] y el intercambio electrónico de datos [EDI]. 
En doce artículos científicos revisados sobre casos de estudio en la materia se observa, de manera general, que es frecuente la utilización del portador de datos DataMatrix GS1 para el sector (Boden et al., 2014; Callan \& Bailey, 2015; Heydrich, 2013; Izquierdo, 2016; Krähenbühl \& Haynes, 2012; Wang \& Chien 2013; Majois, 2013; Marechal \& Jost, 2016; Martínez, 2014; Susuki, 2012; Webb, 2015; Wimmers, 2014). La ventaja que representa es que permite el registro de varios datos (GTIN, No. Serie, fecha de vencimiento, etc.), necesarios para realizar la trazabilidad. Este portador bidimensional, plasmado en formatos muy pequeños del envase primario, posibilita en los hospitales y otras instituciones de salud llevar el control exacto por cada unidad en los procesos de administración del medicamento al paciente; estos centros necesitan para ello la tecnología de captación automática de datos en sus principales procesos (recepción, re-etiquetado, distribución, administración al paciente). El DataMatrix GS1 también se puede utilizar en el envase secundario, aunque se recomienda que vaya acompañado también con el código lineal para garantizar las negociaciones con los socios comerciales que lo utilizan.

La utilización de la tecnología de Identificación por Radio Frecuencia [RFID, Radio Frequency Identification] en el sector de la salud también se ha visto incrementada en los últimos años. La integración de la tecnología RFID para el seguimiento farmacéutico permite optimizar la entrega y la logística del producto, su seguridad y la supervisión de su administración (Jones, Henry, Cochran, \& Frailey, 2010). En la producción y logística, las principales limitaciones de la tecnología óptica (códigos de barras lineales o bidimensional), en comparación con la de RFID (Guido, Mainetti, \& Patrono, 2012), están enfocadas en que limitan la velocidad de operaciones de las líneas de envasado y en las lecturas en las operaciones logísticas.

En algunos estudios realizados se plantea que puede resultar negativo en las características físicas de los medicamentos la utilización de la RFID (Rotunno, Cesarotti, Bellman, Introna, \& Benedetti, 2014), aunque Maffia, Mainetti, Patrono, y Urso (2012) proponen formas seguras para utilizarlos y aprovechar sus potencialidades para el sector. A pesar de esto, la principal limitante para la utilización de etiquetas de RFID son los altos costos que representan, la personalización de software y los sistemas de integración con la tecnología (Guido et al., 2012).

Izquierdo (2016), Callan y Bailey (2015) y Boden et al., (2014) ponen de manifiesto la utilización de la Red Global de Sincronización de Datos [GDSN, Global Data Synchronization Network] para compartir datos maestros de los productos entre los actores de la cadena de suministro. El sistema se conoce como Catálogo Nacional de Producto [NPC, National Product Catalogue], el que según Callan y Bailey (2015) es un registro para todos los productos comercializados en el sector del cuidado de la salud.

El NPG es la única fuente de datos maestros de artículos para instituciones de salud que buscan comprar medica- secure elements: GS1 automatic identification standards and communication standards. This organization counts with 107 member organizations that serve 150 countries (GSI, 2011). In Cuba, its representation is located in the Chamber of Commerce and is named GS1 Cuba.

There are several traceability systems supported in the GS1 standards, such as the National Drug Traceability System in Argentina, the National Tracking and Pharmaceutical Tracking System [ITS] in Turkey, and some pilot tests supported by these standards are being implemented to implement systems national traceability in Brazil, Colombia, and Egypt (Gonzalez, 2013; Bulaon, 2016; Ünal, 2016; Afify \& Mabrouk, 2014; Derecho \& Sánchez, 2014; Filho, Blanco, \& Ferreira, 2011; GS1, 2013; Brommeyer, 2013).

The technologies that allow the implementation of these systems based on the GS1 standards are the automatic identification of product data [Auto-ID] and electronic data interchange [EDI].

In twelve scientific papers reviewed on case studies in the field, it is generally observed that the data carrier DataMatrix GS1 is frequently used for the healthcare sector (Boden et al., 2014; Callan \& Bailey, 2015; Heydrich, 2013; Izquierdo, 2016; Krähenbühl \& Haynes, 2012; Wang \& Chien 2013; Majois, 2013; Marechal \& Jost, 2016; Martínez, 2014; Susuki, 2012; Webb, 2015; Wimmers, 2014). The advantage is that it allows the registration of several data (GTIN, No. Series, expiration date, etc.), necessary to perform the traceability. This two-dimensional carrier, embodied in very small formats of the primary packaging, enables hospitals and other health institutions to carry the exact control for each unit in the process of administering the medication to the patient. These centers need the technology of automatic data collection in their main processes (reception, re-labeling, distribution, administration to the patient). The GS1 DataMatrix can also be used in the secondary packaging, although it is recommended that it also be accompanied by the linear code to guarantee negotiations with the trading partners that use it.

The use of Radio Frequency Identification [RFID] technology in the health sector has also increased in recent years. The integration of RFID technology for pharmaceutical monitoring allows to optimize the delivery and logistics of the product, its security and the supervision of its administration (Jones, Henry, Cochran, \& Frailey, 2010). In manufacturing and logistics, the 
main limitations of optical technology (linear or two-dimensional bar codes), compared to that of RFID (Guido, Mainetti, \& Patron, 2012), are focused on limiting the speed of operations of the packaging lines and in lectures in logistics operations.

In some studies, it is suggested that the use of RFID (Rotunno, Cesarotti, Bellman, Introna, \& Benedetti, 2014) may be negative in the physical characteristics of medicines, although Maffia, Mainetti, Patron, and Urso (2012) propose safe ways to use them and take advantage of their potential for the sector. Despitethis, the main limitation to the use of RFID tags are the high costs they represent, the customization of software and the integration systems with technology (Guido et al., 2012).

Izquierdo (2016), Callan and Bailey (2015), and Boden et al., (2014) highlight the use of the Global Data Synchronization Network [GDSN] to share product master data among the actors in the supply chain. The system is known as the National Product Catalog [NPG], which according to Callan and Bailey (2015) is a register for all products marketed in the health care sector.

The NPG is the only source of master data for health institutions seeking to buy medicines, medical devices and other necessary items in health care. For example, the NPG in Ireland is managed by GS1 Ireland for data synchronization, that is, a certified GDSN database. The existence of this communication standard allows, together with GS1 XML technology and electronic exchange, to optimize the negotiation processes between supply chain partners, as shown in FIGURE 1, where the electronic contracting model is presented developed by

\section{B. Identification of Pharmaceutical} Products in Cuba Drug Supply Chain

As a concept, a product classifier is a system of categories and subcategories of products that allow them to be grouped according to the needs of the activity (OMS, 2007), they have defining attributes that are similar to each other (internally homogeneous), but at the same time, allow to differentiate them from the other categories (externally hetero-

Figure 1. Electronic contracting modeling / Modelo de contratación electrónica (Callan \& Bailey, 2015) mentos, dispositivos médicos y otros artículos necesarios en el cuidado de la salud. Por ejemplo, el NPG en Irlanda está gestionado por GS1 Irlanda para la sincronización de datos, es decir, una base de datos GDSN certificada. La existencia de este estándar de comunicación permite, junto con la tecnología GS1 XML y el intercambio electrónico, optimizar los procesos de negociación entre los socios de la cadena de suministros, como se muestra en la Figura 1, donde se presenta el modelo de contratación electrónica desarrollado por Callan y Bailey (2015).

B. Identificación de los productos farmacéuticos en la cadena de suministro de medicamentos en Cuba

Como concepto, un clasificador de productos es un sistema de categorías y subcategorías de productos que permite agruparlos según las necesidades de la actividad (WHO, 2017), poseen atributos definitorios que son similares entre ellos (internamente homogéneos), pero que, al mismo tiempo, permiten diferenciarlos de las demás categorías (externamente heterogéneos) (INE, 2013). Esto permite que se puedan ordenar y categorizar características de la realidad económica y social de un país, región, ciudad o localidad (INEC, 2012).

Para el desarrollo de un sistema de clasificación de productos se debe considerar, por definición, que los códigos para identificación son diferentes de los códigos para clasificación. Los primeros son usados para hacer una identificación no ambigua de cosas, mientras que los segundos se usan para la agrupación de bienes similares en categorías comunes (CED, 2007).

En la cadena de suministros de medicamentos en Cuba se utiliza el Clasificador Uniforme de Producto [CUP] como un código de identificación de los productos farmacéuticos. Este fue elaborado en los primeros años del decenio de 1970 agrupando bienes de origen industrial y agropecuario. Su estructura se presentaba a nivel genérico, sub-genérico y específico. Dicho clasificador se dejó de actualizar por la Oficina

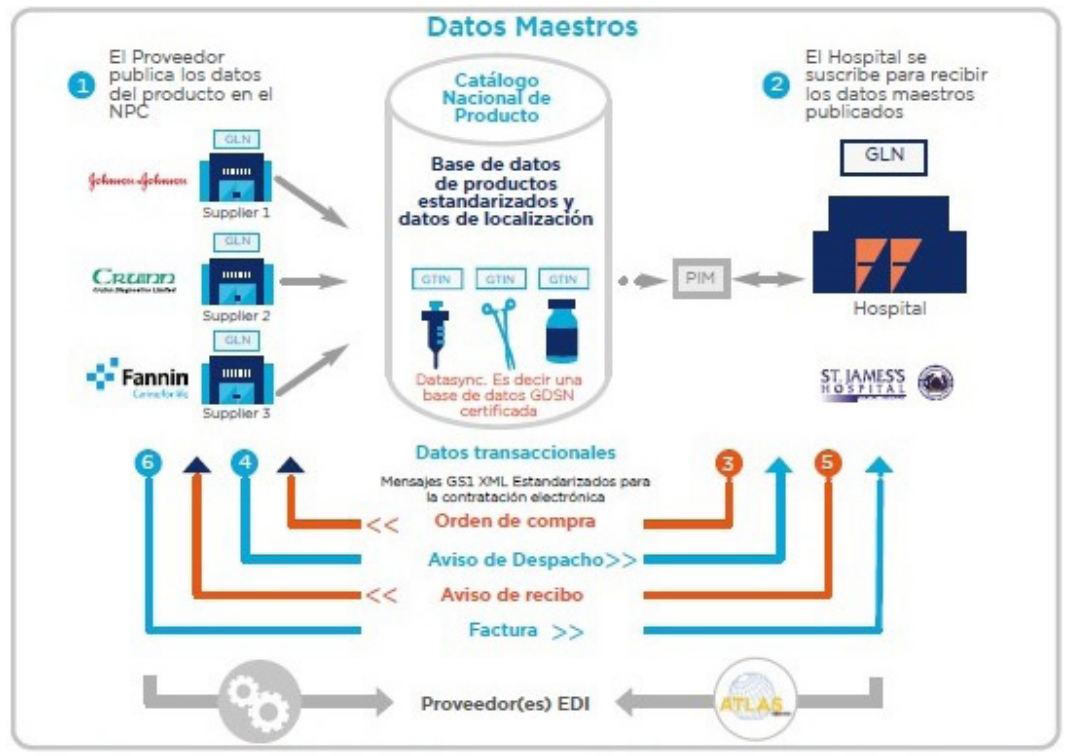




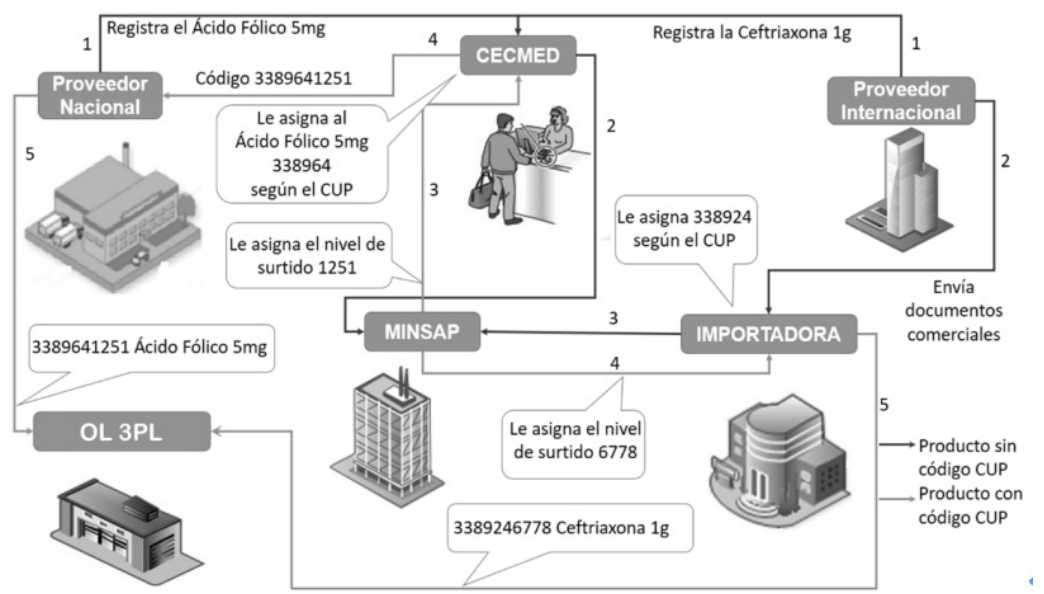

Figure 2. Example of the CUP code assignment for a national and an imported product / Ejemplo de asignación del código CUP para un producto nacional y uno importado

geneous) (INE, 2013). The above allows us to order and categorize characteristics of the economic and social reality of a country, region, city or locality (INEC, 2012).

In order to obtain the development of a product classification system, it should be considered, by definition, that the codes for identification are different from the codes for classification. The first ones are used to make an unambiguous identification of

Nacional de Estadística e Información [ONEI] a inicios de la década del 90, ya que por limitaciones en su nomenclatura y especificaciones metodológicas se hizo obsoleto.

Actualmente en el sector de la salud se continúa utilizando con un nivel más llamado surtido. Este nivel es otorgado por el Departamento de Precios del Ministerio de Salud Pública [MINSAP] y corresponde a las combinaciones de dígitos que están reservadas para una familia determinada para codificar el producto.

La asignación del CUP para los productos nacionales se realiza cuando estos se registran en el CECMED; en el caso de los importados, la asignación es realizada por los importadores, como se muestra en la Figura 2, donde se ilustra la formación actual del código del producto en el sistema de medicamentos.

Para evaluar la situación actual en la identificación de artículos se aplicó el módulo Sistema de Codificación y Clasificación del Modelo de Referencia de Inventario diseñado por Martínez (2013) al Operador Logístico 3PL de la cadena de suministro de medicamentos. El resultado arrojó una evaluación de 2.47 puntos, considerado aceptable; pero los aspectos evaluados se cumplen en un $70 \%$, lo que significa que todavía existen aspectos deficientes, entre ellos la obsoleta utilización del CUP como único código en la cadena.

Los principales errores encontrados en la identificación del producto a partir de evaluar el Sistema de Codificación y Clasificador de Productos son:

- productos con igual código y presentaciones diferentes;

- productos con diferentes códigos e igual presentación;

- productos identificados en su envase con algún estándar internacional pero no en los documentos comerciales;

- ausencia de estandarización de las descripciones;

- empleo de unidades de medida que no corresponden al Sistema Internacional de Unidades [SIU] y que no están estandarizadas;

- la introducción de la información a los sistemas informáticos no se encuentra centrada en el operador logístico 3PL; y

- pobre uso de las tecnologías de identificación automática. things, while the second ones are used to group similar goods into common categories (CED, 2007).

In Cuba drug supply chain, the Uniform Product Classifier [CUP, Clasificador Uniforme de Productos] is used as an identification code for pharmaceutical products. This code was elaborated in the first years of the decade of 1970 grouping goods of industrial and agricultural origin. Its structure was presented at a generic, sub-generic, and specific level. This classifier was discontinued by the National ONEI at the beginning of the $90 \mathrm{~s}$, due to limitations in its nomenclature and methodological specifications became obsolete.

Currently in the health sector continues to be used with a level called assortment. This level is granted by the Ministry of Public Health [MINSAP, Ministerio de Salud Pública] and corresponds to the combinations of digits that are reserved for a specific family to code the product.

The CUP allocation for national products is done when these are registered in the CECMED; for imported products, the allocation is done by their importers, as shown in Figure 2, where the current formation of the product code in the drug system is illustrated.

To evaluate the current situation in the identification of items, the Coding System and Classification System of the Inventory Reference Model designed by Martínez (2013) was applied to the 3PL Logistic Operator of the drug supply chain. The result yielded an evaluation of 2.47 points, considered acceptable; but the aspects evaluated are met by $70 \%$, which means that there are still deficient aspects, among them the obsolete use of the GUP as the only code in the chain.

The main errors found in the product identification from the evaluation of the Coding System and Classifier of Products are: 
- Products with the same code and different codes;

- products with different packing and the same presentation;

- products identified on their packaging with an international standard but not in commercial documents;

- absence of standardization in descriptions;

- use of measurement units that do not correspond to the International System of Units [ISU] and that are not standardized;

- introduction of information to computer systems not centered on the 3PL logistics operator; and

- poor use of automatic identification technologies.

In Figure 3 appears examples of the above errors.

When the pharmaceutical product arrives at the healthcare centers, it is given an entry in the inventory through the introduction of its data in the computer system. The above are entered manually and through the name that already exists in the system, not through the code, which brings as a consequence that the same product, with the same dosage, but with a different code (is expressed in the bill), is reflected in the system with the same code, a situation that affects traceability.

One of the final actors in this chain are community pharmacies. Only those located in three municipalities of Havana have computerized media and scanners at the Point of Sale [POS], while the rest do not have any technology.

In both types of pharmacies, the inventory management is carried out, with the main identifier as the
Ejemplos de estos se evidencian en la Figura 3.

$\mathrm{Al}$ arribar el producto farmacéutico a los centros asistenciales se le da entrada en el inventario a través de la introducción de sus datos en el sistema informático, estos se introducen manualmente y a través del nombre que ya existe en el sistema, no por el código, lo que trae como consecuencia que un mismo producto, con la misma dosificación, pero con un código diferente (se plasma en la factura), esté reflejados en el sistema en un mismo código, situación que afecta la trazabilidad.

Uno de los actores finales de esta cadena son las farmacias comunitarias, de ellas solo las que radican en tres municipios de La Habana cuentan con medios computarizados y escáneres en el punto de venta, mientras que el resto no tiene ninguna tecnología.

En ambos tipos de farmacias se realiza la gestión del inventario teniendo como identificador principal el nombre del producto y no su código, por lo que se dan las mismas situaciones de los centros asistenciales. Este problema se refleja solamente en las tarjetas de estiba o kardex, y no en el sistema informático, para el caso de las farmacias sin ningún tipo de tecnología.

En general, la percepción es que el aspecto financiero es la limitante para implementar la identificación automática en la cadena de suministros de medicamentos, pero en opinión de estos autores es prioritaria la implementación de estándares de codificación globales, como los códigos GTIN o números de identificación de artículos comerciales [Global Trade Identification Number].

En Cuba esta problemática afecta a todos los sectores de la economía (Martínez, 2014).

C. Procedimiento para la implementación de las tecnologías Auto-ID y EDI en la cadena de suministro de medicamentos en Cuba

A partir de las características de los estándares GS1, que sustentan el uso de las tecnologías Auto-ID y EDI, se diseñó un procedimiento para implementarlos en la cadena de suministros de medicamentos en Cuba, con el objetivo de incrementar su seguridad y eficiencia. El procedimiento tiene un alcance a toda la

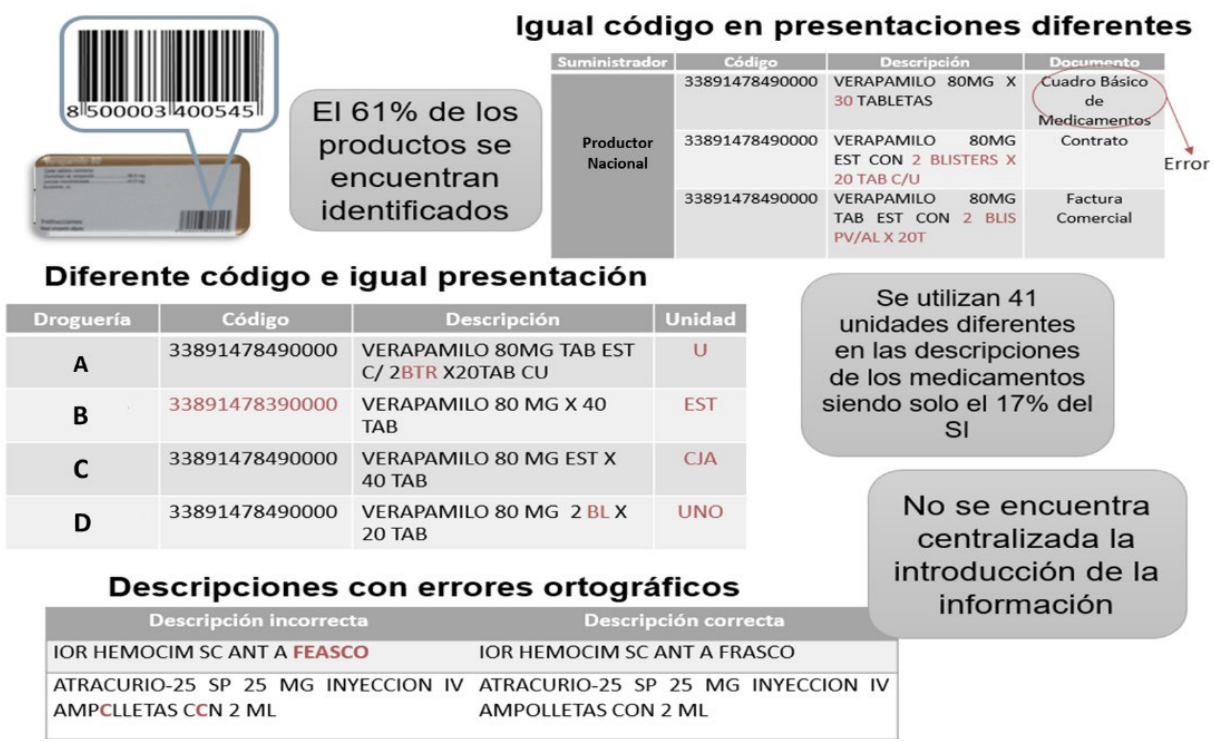

Figure 3. Issues in the coding and classification system / Problemas en el sistema de codificación y clasificación 

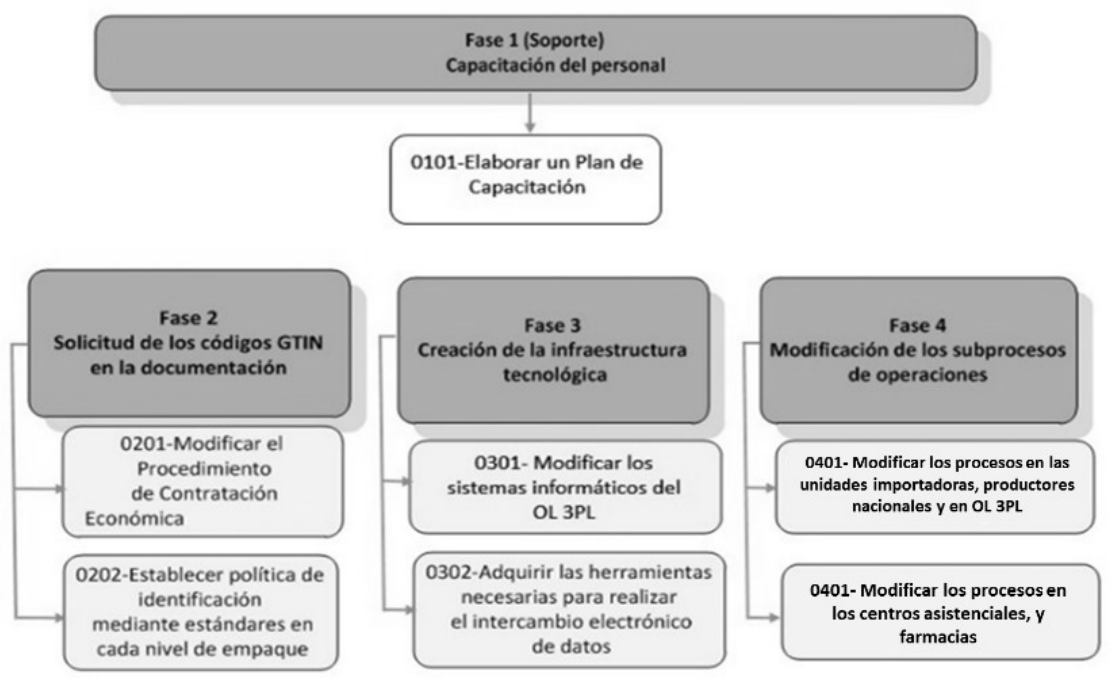

cadena de suministros y consta de cuatro etapas, según se muestra en la Figura 4.

La propuesta de los estándares de códigos a utilizar para la identificación de cada nivel de empaque de los productos farmacéuticos se expone en la Figura 5, todos sustentados en la ISO 15459:2014.

En la Fase 3 es importante tener en cuenta que la correcta selección de los escáneres de códigos radica en el grado de correspondencia que se logre entre las condiciones de uso, los requerimientos del proceso donde va a ser empleado y las características técnicas del scanner.

\section{Discusión}

$\mathrm{Al}$ analizar el estado del sistema de codificación y clasificación de la cadena de suministro de medicamentos en Cuba se observa como una debilidad importante la inefectividad de la identificación de los medicamentos. Esta situación puede afectar las retiradas de productos del mercado o el seguimiento que se le pueda realizar a determinados productos con diferentes fines, tanto comerciales, como investigativos, ante alertas de calidad.
Figure 4. Procedure stages for the implementation of Auto-ID and EDI /

Etapas del procedimiento para la implementación de Auto-ID y EDI

name of the product and not its code, which is because the same situations occur in health care centers. In the case of pharmacies without any type of technology, this issue is only reflected in the stowage or kardex cards, and not in the computer system.

In general, the perception is that the financial aspect is the restriction to implement automatic identification in the drugs supply chains. However, considering the opinion of these authors, is a priority to consider the implementation of global coding standards, such as Global Trade Identification Number [GTIN] codes or commercial items identification numbers. In Cuba, this issue affects all the economy sectors (Martínez, 2014).

C. Procedure for Auto-ID and EDI Technologies Implementation in Cuba Drugs Supply Chain

Based in the characteristics of GS1 standards, which support the use of Auto ID and EDI technologies, a procedure is designed to be implemented in Cuba drugs supply chain, in order to increase their safety and efficiency. The procedure has a scope throughout the supply chain and consists of four stages, as shown in Figure 4.

The proposal of the standards codes to be used for the identification of each level of pharmaceutical products

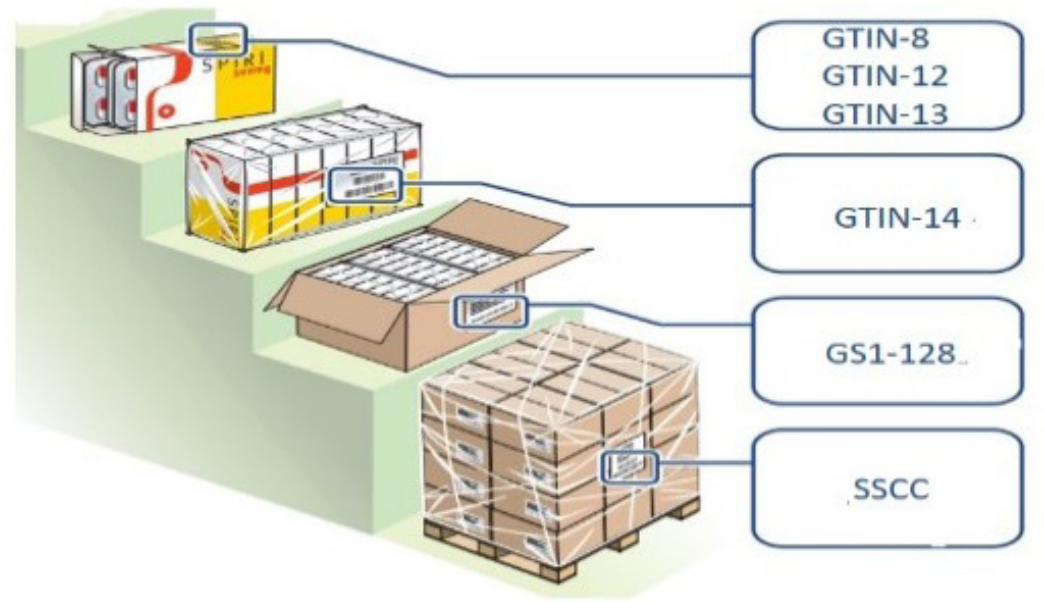

Figura 5. Codes according to packing level / Códigos por nivel del empaque 
packaging is shown in FIGURE 5, all supported by ISO 15459:2014.

In Phase 3 it is important to consider that the right selection of code scanners depends on the correspondence level achieved between the use conditions, the process requirements, and the technical characteristics of the scanner.

\section{Discussion}

When analyzing the status of the coding and classification system of the drug supply chain in Cuba, the ineffectiveness of drug identification is seen as an important weakness. This situation can affect the withdrawals of products from the market or the monitoring that can be done to certain products with different purposes, both commercial and investigative, with respect to quality alerts.

These systems supported by the Auto-ID and EDI technologies allow safer and more efficient supply chains, since they guarantee the implementation of efficient traceability systems, such as the cases seen in section III. A of this article.

According to the proposed procedure, the implementation of the Auto-ID and EDI in Cuba drugs supply will allow obtaining benefits such as:

- Increase the security of the service provided to the population;

- improve the stocks management;

- decrease illegal activities;

- control costs and logistics cycles; and

- improve the evaluation of quality control and productivity.

The implementation of these technologies represents high costs for the sector, which is why it is necessary to perform analyzes to evaluate and contrast the risks and benefits, both economic and social, that will allow the Auto-ID and the EDI, based on the premise that at a higher technological level the chain will present lower security risks and will be more efficient.

\section{Conclusions}

The analysis of the current state of the coding and classification system allows us to identify that the main deficiencies in the identification of the product are: the use of an obsolete classifier, such as an encoder, that has brought various issues as the assignment of two codes for the same product, and that two products with different
Estos sistemas, sustentados en las tecnologías Auto-ID y EDI, permiten cadenas de suministros más seguras y eficientes, ya que garantizan la implementación de eficientes sistemas de trazabilidad, como son los casos vistos en la sección III. A del presente artículo.

La implementación de la Auto-ID y EDI en la cadena de suministro de medicamentos en Cuba según el procedimiento propuesto permitirá obtener beneficios como:

- aumentar la seguridad del servicio que se le brinda a la población;

- mejorar la gestión de los inventarios;

- disminuir las actividades ilegales;

- controlar los costos y ciclos logísticos; y

- mejorar la evaluación del control de calidad y la productividad.

La implementación de estas tecnologías representa altos costos para el sector, es por eso que se hace necesario realizar análisis para evaluar y contraponer los riesgos y beneficios, tanto económicos, como sociales, que permitirán la Auto-ID y el EDI, teniendo como base la premisa de que a un mayor nivel tecnológico la cadena presentará menores riesgos en su seguridad y será más eficiente.

\section{Conclusiones}

El análisis del estado actual del sistema de codificación y clasificación permite identificar que las principales deficiencias en la identificación del producto son: se utiliza un clasificador obsoleto, como un codificador, lo que ha traído diversos problemas como la asignación de dos códigos para un mismo producto y que dos productos con presentaciones diferentes tengan el mismo código; se utilizan 41 unidades de medida diferentes en las descripciones de los medicamentos, de las que solo el 17\% del sistema internacional de medida; y no se encuentra centralizada la introducción de información al sistema que posibilita la existencia de varias descripciones para un mismo producto y con diferentes unidades de medidas, además de propiciar en los centros asistenciales y las farmacias la introducción de la existencia en inventario en códigos incorrectos.

El no uso de los estándares de codificación por los actores de la cadena limita considerablemente la implementación de las tecnologías de Auto-ID.

Para la implementación eficiente de las tecnologías Auto-ID y EDI se propone un procedimiento de cuatro fases sustentado en la modificación de los procesos actuales. Se recomienda que los procesos en el sistema de medicamentos sean diseñados incluyendo la implementación de la identificación automática, con el objetivo de garantizar su trazabilidad, desde el origen del producto hasta el paciente cliente del medicamento. Aunque esto está declarado en la literatura y en los casos de estudio analizados, se considera que existe una carencia en la estandarización de un procedimiento que pueda ser implementado de forma generalizada en diferentes tipos de servicios de salud. 
Otro elemento a desarrollar en futuras investigaciones está relacionado con el diseño de una herramienta que permita, a partir del análisis de un proceso logístico, decidir los tipos de scanner que deben utilizarse, dado que es difícil para el logístico decidir solo teniendo en cuenta las características técnicas y precios. SAT presentations have the same code; 41 different units of measurement are used in the descriptions of medicines, but of them, only $17 \%$ corresponding to the international measurement system; and it is not centralized the introduction of information to the system that allows the existence of several descriptions for the same product and with different units of measures, as well as encouraging in the health centers and pharmacies the stock introduction in wrong codes.

The non-use of the coding standards by the actors of the chain considerably limits the implementation of Auto-ID technologies. For the efficient implementation of Auto-ID and EDI technologies, a four-stage procedure, supported in the modification of actual process.

It is recommended that the processes in the drug system be designed including the implementation of automatic identification, in order to guarantee its traceability, from its origin to the patient. Although this is stated in the literature and in the case studies analyzed, it is considered that there is a lack of standardization of a procedure that can be implemented in a generalized manner in different types of health services.

Another element to be developed in future researches is the design of a tool to decide, from the analysis of logistical process, the class of scanners to be used, because it is hard for the logistics to decide just based in technical aspects and prices. SAT 


\section{References / Referencias}

Afify, A. M. \& Mabrouk, M. (2014). Safemed mantiene los medicamentos falsificados fuera de la cadena de abastecimiento en Egipto. In Guía de referencia GS1Healthcare 2013/2014, (pp. 17-22). México: GS1.

Boden, R. Wagener, S., \& Sinha, I. (2014). Las Pequeñas y Medianas Empresas lideran el camino con los Estándares GS1. In Guía de referencia GS1Healthcare 2013/2014, (pp. 11-15). México: GS1.

Brommeyer, M. (2013). Healthcare suppliers benefiting from Global Data Synchronisation. In: GS1 Healthcare Reference Book 2012/2013, (pp. 4-10). Brussels, Belgium: GS1.

Bulaon, V. (2016). NSW Health continúa beneficiándose de la implementación de los estándares GS1. In: Manual de Referencia GS1 Healthcare 2015-2016: implementaciones exitosas de los estándares GS1, (pp. 42-45). Buenos Aires, Argentina: GS1.

Callan, P. V. \& Bailey, P. (2015). La contratación electrónica (eProcurement) en el Hospital St. James, Dublin. In: Manual de Referencia GS1 Healthcare 2015-2016: implementaciones exitosas de los estándares GS1, (pp. 23-28). Buenos Aires, Argentina: GS1.

Centro para el Control Estatal de Medicamentos, Equipos y Dispositivos Médicos [CECMED]. (2017). Vigilancia postcomercialización. Retrieved from: http://www.cecmed.cu/tipo-de-funcion/vigilancia-postcomercializacion

Comercio ilegal de medicamentos, un peligro mortal para la salud. (2010). Retrieved from: http://boletinseps.blogspot. com/2010/02/comercio-ilegal-de-medicamentos-un.html

Consultorías Empresariales Delfos [CED]. (2007). Sistemas de clasificación internacional.

Derecho, M. \& Sánchez, M. J. (2014). ANMAT marcando el camino. In: Guía de referencia GS1 Healthcare 2013/2014, (pp. 5-7). México: GS1.

Ferrer-Roca, O. (2011). Standards in telemedicine. In: E-Health systems quality and reliability: Models and standards: Models and Standards, (pp. 220-243). Hershey, PA: IGI GLobal.

Filho, A. F. M., Blanco, P., \& Ferreira, L. (2011). Proyecto piloto de sistema de trazabilidad de productos farmacéuticos en Brasil. In: Guía de Referencia de GS1 Healthcare 2010/2011, (pp. 9-12). Buenos Aires, Argentina: GS1.

Gonzalez, J. E. (2013). Deployment of a traceability system by a pharmaceutical wholesaler leveraging GS1 Standards. In: GS1 Healthcare Reference Book 2012/2013, (pp. 19-22). Brussels, Belgium: GS1.

GS1. (2011). El valor y los beneficios del sistema de estándares GS1. Buenos Aires, Argentina: GS1.

GS1. (2013). Healthcare case study: Healthcare suppliers benefiting from global data synchronization. Mount Waverley, Australia: SG1.

Guido, A. L., Mainetti, L., \& Patrono, L. (2012). Evaluating potential benefits of the use of RFID, EPCglobal, and ebXML in the pharmaceutical supply chain. International Journal of Healthcare Technology and Management, 13(4), $198-222$. doi:10.1504/IJHTM.2012.050625.

Heydrich, J. (2013). Implementing GS1 datamatrix at Moinhos de Vento Hospital: Ensuring drug traceability and patient safety. In: GS1 Healthcare Reference Book 2012/2013, (pp. 15-18). Brussels, Belgium: GS1.

Instituto Nacional de Estadísticas [INE]. (2013). Manual de codificación y supervisión. Santiago de Chile: INE.

Instituto Nacional de Estadísticas y Censos [INEC]. (2012). Clasificación nacional central de productos. Quito, Ecuador: INEC.

ISO/IEC FDIS 15459-4:2014 - Information technology - Automatic identification and data capture techniques - Unique identification - Part 4: Individual products and product packages. Geneva, Switzerland: ISO

ISO/IEC 15424:2008 - Information technology - Automatic identification and data capture techniques — Data Carrier Identifiers (including Symbology Identifiers). Geneva, Switzerland: ISO

ISO 17367:2013- Supply chain applications of RFID - Product tagging. Geneva, Switzerland: ISO

ISO/FDIS 29161:2016 - Information technology - Data structure - Unique identification for the Internet of Things. Geneva, Switzerland: ISO.

Izquierdo, D. E. (2016). El Sanatorio Güemes mejora la seguridad del paciente mediante la iniciativa de trazabilidad. In: Manual de Referencia GS1 Healthcare 2015-2016: implementaciones exitosas de los estándares GS1, (pp. 8-11). Buenos Aires, Argentina: GS1.

Jones, E., Henry, M., Cochran, D., \& Frailey, T. (2010). RFID pharmaceutical tracking: From manufacturer through in vivo drug delivery. Journal of Medical Devices, 4(1). doi:10.1115/1.4000495

Krähenbühl, C., \& Haynes, I. (2012). Uso de Estándares GS1 para combatir la falsificación y mejorar la seguridad del paciente. . In: Guía de Referencia de GS1 Healthcare 2011/2012, (pp. 51-53). Buenos Aires, Argentina: GS1.

Maffia, M., Mainetti, L., Patrono, L., \& Urso, E. (2012). Potential impact of RFID-based tracing systems on the integrity of pharmaceutical products Advanced RFID Systems. In: Advanced RFID systems, security, and applications, (pp. 241-263): Hershey, PA: IGI Global.

Majois, P. (2013). Baxter endorses GS1 standards as a building block of brand integrity programme. In: GS1 Healthcare Reference Book 2012/2013, (pp. 13-14). Brussels, Belgium: GS1.

Marechal, B. \& Jost, V. (2016). Permitiendo la trazabilidad en el Hospital Universitario Dijon mediante la identificación de todas las habitaciones y localizaciones. In: Manual de Referencia GS1 Healthcare 2015-2016: implementaciones exitosas de los estándares GS1, (pp. 19-22). Buenos Aires, Argentina: GS1. 
Martínez, I. L. (2013). Modelo de referencia para la evaluación de la gestión de inventarios en los sistemas logísticos [thesis]. Universidad tecnológica de La Habana: Cuba.

Martínez, I. L. (2014). Problemas de codificación de productos que afectan la gestión de inventarios: Caso de estudio en empresas cubanas. DYNA, 81(187), 64-72. doi: 10.15446/dyna.v81n186.40070

NC-ISO 22005:2008: Trazabilidad de la cadena alimentaria — principios generales y requisitos fundamentales para el diseño y la implementación del sistema. La Habana, Cuba: Oficina Nacional de Normalización [NC].

Organización Mundial de la Salud [OMS]. (2007). Proyecto de elaboración de una clasificación internacional para la seguridad del paciente: informe de los resultados de la encuesta Delfos sobre la introducción a la clasificación internacional para la seguridad del paciente. Ginebra, Suiza: OMS.

Park, S., Zo, H., Ciganek, A. P., \& Lim, G. G. (2011). Examining success factors in the adoption of digital object identifier systems. Electronic Commerce Research and Applications, 10(6), 626-636.

Rotunno, R., Cesarotti, V., Bellman, A., Introna, V., \& Benedetti, M. (2014). Impact of track and trace integration on pharmaceutical production systems. International Journal of Engineering Business Management, 6(25). doi:10.5772/58934

Suzuki, R. (2012). La administración de logística de productos farmacéuticos con códigos de barras y etiquetas RFID, TBC Tokio, Toho Pharmaceutical Co. Ltda. In: Guía de Referencia de GS1 Healthcare 2011/2012, (pp. 35-39). Buenos Aires, Argentina: GS1.

Ünal, P. Ö. (2016). Turquía implementa el primer sistema nacional exitoso de rastreo y seguimiento farmacéutico (ITS) para una cadena de abastecimiento segura y confiable. In: Manual de Referencia GS1 Healthcare 2015-2016: implementaciones exitosas de los estándares GS1, (pp. 46-49). Buenos Aires, Argentina: GS1.

Wang, L-Ch \& Chien, S-Y. (2013). TFDA, CCH and GS1 Taiwan advancing GS1 barcodes to improve patient safety. In: GS1 Healthcare Reference Book 2012/2013, (pp. 30-32). Brussels, Belgium: GS1.

Webb, J. (2015). Kent Pharmaceuticals: una serialización farmacéutica y un sistema de verificación en vivo. In: Manual de Referencia GS1 Healthcare 2014-2015: doce historias de implementación exitosas, (pp. 41-44). Buenos Aires, Argentina: GS1.

Wimmers, H. (2014). Implementación de la trazabilidad de medicamentos en el Hospital Alemán en Argentina. In: Guía de referencia GS1 Healthcare 2013/2014, (pp. 8-10). México: GS1.

World Health Organization [WHO]. (2017). Global surveillance and monitoring system for substandard and falsified medical products. Geneva, Switzerland: WHO. 


\section{CURRICULUM VITAE}

Igor Lopes Martínez Doctor in Technical Sciences, Industrial Engineer, specialized in Business Organization. Professor at the Faculty of Industrial Engineering of CUJAE, Head of the Department of Industrial Engineering. Member of the research group of Logistics and Production Management [LOGESPRO]. Senior Professor of logistics and supply chain topics in undergraduate and postgraduate education / Doctor en Ciencias Técnicas. Graduado de Ingeniería Industrial, especializado en Organización de Empresas. Profesor de la Facultad de Ingeniería Industrial de la CUJAE, Jefe del Departamento de Ingeniería Industrial. Miembro del grupo de investigación de Logística y Gestión de la Producción [LOGESPRO]. Profesor titular en temas de logística y cadena de suministros en pregrado y posgrado.

Lianet Paradela Fournier Industrial Engineer, professor at the Faculty of Industrial Engineering of the CUJAE (Havana, Cuba). Member of the Logistics and Production Management research group [LOGESPRO]. Instructor professor in logistics and supply chain in undergraduate and postgraduate courses / Ingeniera Industrial, profesora de la Facultad de Ingeniería Industrial de la CUJAE. Miembro del grupo de investigación de Logística y Gestión de la Producción [LOGESPRO]. Profesora Instructora en temas de logística y cadena de suministros en pregrado y posgrado.

Janett Rodríguez Acosta Industrial Engineer, professor at the Industrial Engineering Faculty of the CUJAE (Havana, Cuba). Member of the Logistics and Production Management research group [LOGESPRO]. Trained teacher in logistics and supply chain in undergraduate education / Ingeniera Industrial, profesora de la Facultad de Ingeniería Industrial de la CUJAE. Miembro del grupo de investigación de Logística y Gestión de la Producción [LOGESPRO]. Profesora adiestrada en temas de logística y cadena de suministros en pregrado.

Jenny Laura Castillo Feu Industrial Engineer, professor at the Industrial Engineering Faculty of the CUJAE (Havana, Cuba). Member of the Logistics and Production Management research group [LOGESPRO]. Trained teacher in logistics and supply chain in undergraduate education / Ingeniera Industrial, profesora de la Facultad de Ingeniería Industrial de la CUJAE. Miembro del grupo de investigación de Logística y Gestión de la Producción (LOGESPRO). Profesora Adiestrada en temas de logística y cadena de suministros en pregrado.

Martha I. Gómez Acosta Ph.D. in Technical Sciences and Industrial Engineer. Professor at the Faculty of Industrial Engineering of the CUJAE. Executive Coordinator of the Logistics and Production Management Laboratory [LOGESPRO]. She is member of the European-Latin American Center for Logistics and Ecological Projects [CELALE] and professor of logistics and supply chain issues in undergraduate and postgraduate education / Doctora en Ciencias Técnicas. Graduada de Ingeniería Industrial. Profesor de la Facultad de Ingeniería Industrial de la CUJAE. Coordinadora Ejecutiva de Laboratorio de Logística y Gestión de Producción [LOGESPRO]. Miembro de la Centro Europeo-Latinoamericano de Logística y Proyectos Ecológicos [CELALE]. Profesora titular en temas de logística y cadena de suministros en pregrado y posgrado.

Alegna Cruz Ruiz Master in Social Psychology. Bachelor in Psychology from the Universidad de La Habana [UH](Cuba). Professor at the Faculty of Psychology of the UH. Second Head of the Department of Exercise of the Profession and Assistant Professor of organizational psychology and organizational communication / Máster en Psicología Social. Licenciada en Psicología por la Universidad de La Habana [UH] (Cuba). Profesora de la Facultad de Psicología de la UH. Segunda jefa del Departamento de Ejercicio de la Profesión y profesora auxiliar de temas de psicología organizacional y comunicación organizacional. 